\title{
SPATIAL DISTRIBUTION OF KIMBERLITE IN THE SLAVE CRATON: A GEOMETRICAL APPROACH
}

\author{
Mike Stubley \\ Stubley Geoscience, Canada
}

\section{INTRODUCTION}

The recognition of tectonic or other features that controlled the emplacement of kimberlite is fundamental to diamond exploration methodologies, yet our understanding of these relationships is in its infancy. Exploration within the Slave craton has revealed clusters or "fields" of kimberlite, commonly with internally consistent geochemical or temporal characteristics. However, the spatial relationship between kimberlite within and between the clusters remains enigmatic.

Vearncombe and Vearncombe (2002) present a novel and purely geometrical approach to investigate tectonic controls on kimberlite location within southern Africa. A similar analysis has been conducted for the Slave craton and forms the basis for this paper.

\section{METHODOLOGY}

For a non-random distribution of points, it may be possible to recognize inherent patterns by using centreto-centre (point-to-point) techniques of spatial analysis. Fry (1979) presented a simple, yet elegant, graphical variant of this technique to evaluate strain in deformed rocks. The so-called "Fry analysis" examines the spatial relationship between each point and all others in the database. Each point is, in turn, placed at a common origin and all other points are plotted in their respective new position resulting in a composite plot with $n^{2}$ points (including $n$ points on the origin). Recurrent patterns, including distance and orientation from the origin, are visually accentuated due to the square function in data density.

The current analysis uses the geographic position of all reported kimberlite occurrences in the Slave craton $(n=$ 212) as the base template. Publicly available locations are taken primarily from Jones (2002) and Wright (1999). Computer-assisted copying and overlaying of the entire template so that each kimberlite is in turn on the origin results in a symmetrical Fry Plot with ca. 45,000 points. Circular histograms are constructed to display data density within $5^{\circ}$ azimuthal sectors for a variety of distances from the origin.

\section{SPATIAL ANALYSIS}

\section{TEMPLATE OF SLAVE KIMBERLITE LOCATIONS}

Kimberlite occurrences of the Slave craton can be grouped into five broad clusters (Fig. 1); only two pipes appear isolated from this simplistic subdivision. The Central Slave cluster is further subdivided to delimit the dense kimberlite distribution of the Lac de Gras region (Fig. 1).

Clusters in the western craton are elongate to the northnortheast and appear to align within a narrow northnortheast trending zone (Western Corridor of Fig. 1). Elsewhere, the clusters are elongate to the northwest or west-northwest and appear to be arranged en echelon within a poorly defined north-northwest trending zone (Central Corridor of Fig. 1).

\section{FRY ANALYSIS}

The point-to-point graphical analysis has been conducted for the entire Slave database. The dense distribution within the Lac de Gras field (70\% of the data) tends to overwhelm and mask the relationships in other clusters. In an attempt to test for local and regional variations, the analysis has also been conducted separately on kimberlite locations within and external to the Lac de Gras field.

Figure 2 presents the results of analysis of the data external to the Lac de Gras field. The Fry Plot shows a preference for kimberlite to be located to the northnorthwest or north-northeast (or their complementary directions) of other occurrences, and this reflects the broad distribution within the two first-order corridors. Figure $2 \mathrm{~d}$ quantifies these craton-scale relationships, and its smaller peaks reflect the west-northwest alignment of data clusters superposed on the Central Corridor. At regional scales of observation (e.g. $<100$ $\mathrm{km}$ radius; Fig. $2 \mathrm{a} \& \mathrm{~b}$ ), the prominent orientations (west-northwest and north-northeast) reflect the distribution within the elongate clusters. A prominent northeast-southwest alignment is constrained within 25 
$\mathrm{km}$ of the origin and likely reflects the linear distribution of kimberlite in the Kennady Lake area of the Southeast Slave cluster (see Fig. 1).

Similar, although less distinct, regional and local relationships are evident from Fry analysis of the Lac de Gras kimberlite field (Fig. 3). A preference for kimberlite to be located to the northeast-southwest of other occurrences is evident only when considering distances of less than ten kilometres (Fig. 3a). Moreprominent preferential alignments to the north-northeast and west-northwest (or their complementary directions) persist to distances of about $50 \mathrm{~km}$ (Fig. 3c). At greater distances, the general northwest elongation of the field dominates the analysis.

\section{DISCUSSION}

A prominent system of east-northeast (ca. $070^{\circ}$ ) trending fractures (faults, lineaments, dykes) characterizes the south and central Slave craton. Kimberlite is commonly encountered within or adjacent to these fractures (e.g. Wright, 1999), and this empirical spatial association has aided successful exploration. It may be somewhat surprising, then, that the Fry analyses fail to highlight this association. It is postulated that the $070^{\circ}$ fractures exerted only near-surface influence on kimberlite emplacement, and had minimal effect on localization at scales exceeding several kilometres.

The Fry analyses reveal a strong preference for kimberlite to be located to the west-northwest (ca. 280 ${ }^{\circ}$ ) of other occurrences within all clusters of the Central Corridor. At a regional scale, this orientation corresponds approximately to the general elongation of each of the eastern clusters (Fig. 1). Kilometre-scale associations are exemplified by a swath of pipes (including Diavik's “T-“" series) in the southern Lac de Gras field (Fig. 1). West-northwest oriented features of the crustal geology are poorly represented in the Slave craton, although diabase dykes of the MacKay swarm and associated fractures follow this trend in the area southeast of Lac de Gras (Wilkinson et al., 2001). This generally cryptic relationship with crustal features may suggest lower- or sub-crustal control on the preferential kimberlite localization.

A preference for kimberlite to be dispersed northnortheast (ca. $015^{\circ}$ ) of other occurrences is evident in all analyses at all scales. The Western Corridor and its contained clusters reflect this dispersion at craton and regional scales (Fig. 1). At a local scale, the alignment of pipes slated for exploitation at both the Ekati ${ }^{\mathrm{TM}}$ and
Diavik mine sites follows this trend within the Lac de Gras field.

Within the Central Corridor, the ca. 2.02 Ga rift-related alkaline "Lac de Gras" diabase dyke swarm (LeCheminant, 1994; Wilkinson et al., 2001) parallels the north-northeast kimberlite dispersion trend. Geological mapping and interpretation of aeromagnetic data suggest the dykes are concentrated within a ca. 30 km-wide corridor that passes through Lac de Gras. All kimberlite currently slated for production within the Slave craton is located along the margins of the dyke corridor (Fig. 4). The profound spatial association between kimberlite ore and the Lac de Gras diabase dykes is currently being evaluated. Preliminary interpretations suggest the dyke corridor reflects a mantle-depth feature that has been repeatedly exploited by alkaline magma. Perhaps the Western Corridor is indicative of a parallel and analogous conduit system; this narrow zone also hosts one of only two known Archean carbonatites in the Slave craton (Stubley \& Cairns, 1998). The cause of the apparently enhanced diamond potential at the dyke-corridor margins in kimberlite of disparate age, however, remains speculative.

\section{REFERENCES}

Fry, N., 1979. Random point distributions and strain measurements in rocks. Tectonophysics 60, 89-105.

Jones, G.E., 2002. Lac de Gras Exploration Area. Mineral Information Maps, Calgary, Canada.

LeCheminant, A.N., 1994. Proterozoic diabase dyke swarms, Lac de Gras and Aylmer Lake areas, District of Mackenzie, Northwest Territories. Geological Survey of Canada, Open File 2975.

Stubley, M.P., Cairns, S.R., 1998. Geology of the Fishing Lake area, southern Slave Province (Parts of NTS 85 $\mathrm{O} / 1 \& 8$ and $85 \mathrm{P} / 5$ ). NWT Geology Division DIAND, Yellowknife, EGS 1998-5.

Vearncombe, S., Vearncombe, J.R., 2002. Tectonic controls on kimberlite location, southern Africa. Journal of Structural Geology 24, 1619-1625.

Wilkinson, L., Kjarsgaard, B.A., LeCheminant, A.N., Harris, J., 2001. Diabase dyke swarms in the Lac de Gras area, Northwest Territories, and their significance to kimberlite exploration: initial results. Geological Survey of Canada, Current Research 2001-C8, 17p.

Wright, K.-J., 1999. Possible structural controls of kimberlites in the Lac de Gras region, central Slave Province, Northwest Territories, Canada. M.Sc. Thesis, Queen's University, Kingston, Canada.

Contact: MP Stubley, 158 Toki Rd., Cochrane, AB, Canada,

T4C 2A2, E-mail: stubley@ pathcom.ca 


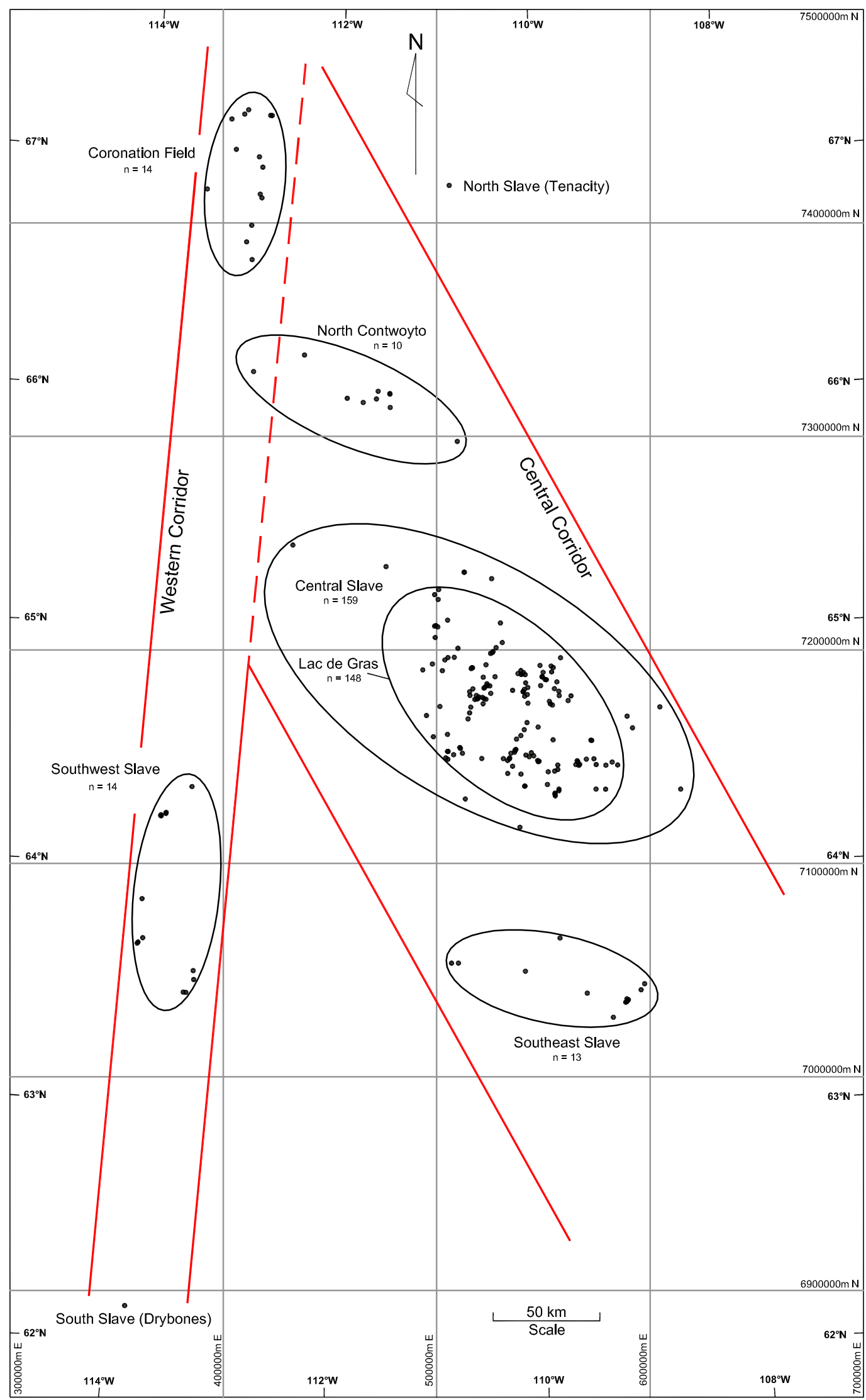

Figure 1: Distribution of reported kimberlite $(\mathrm{n}=212)$ within the Slave Craton. Ellipses delimit "fields" or spatial clusters of kimberlites, as discussed in text. Orthogonal grid is based on Universal Transverse Mercator projection (NAD 83, Zone 12). 


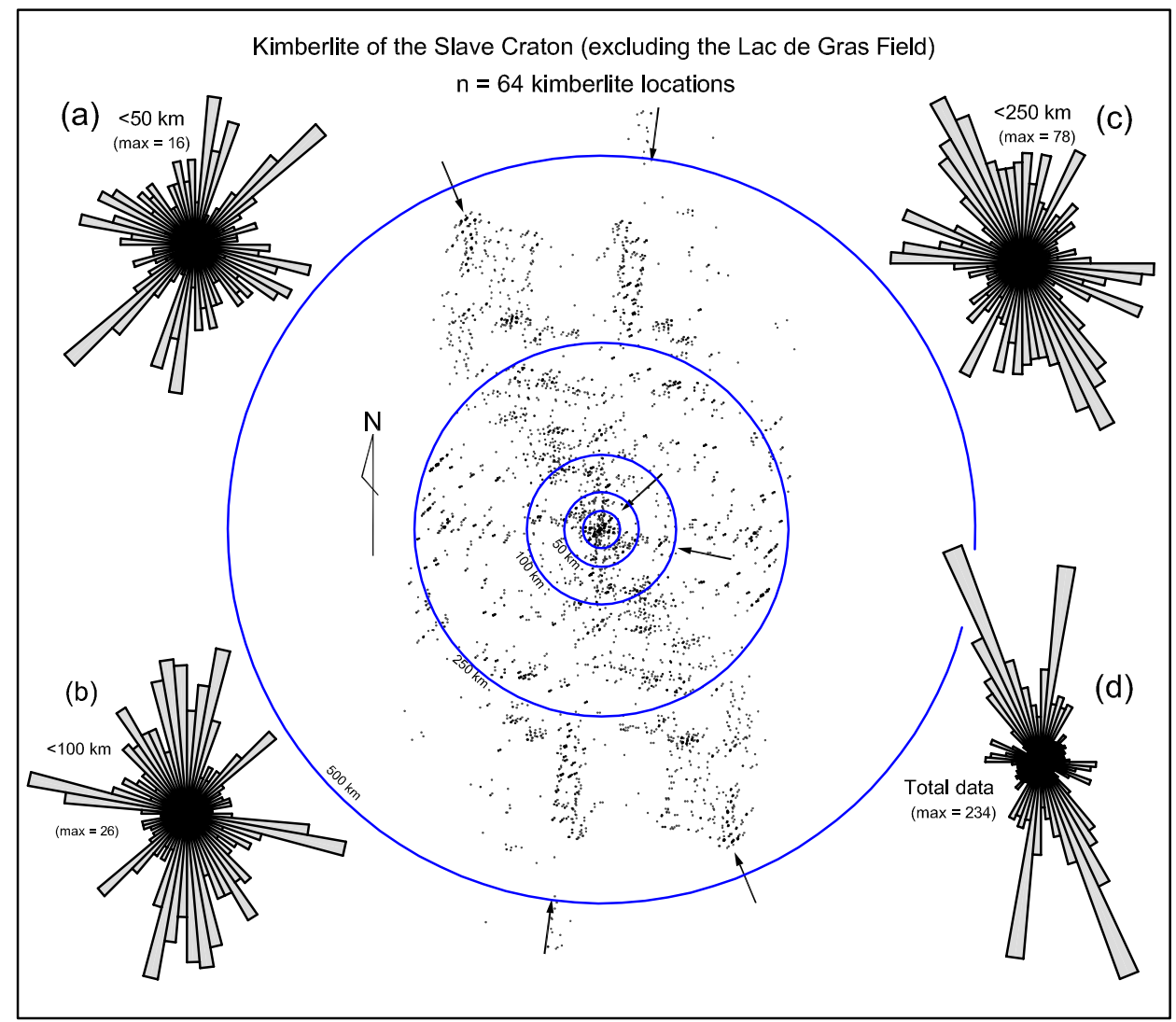

Figure 2: "Fry Plot" for kimberlite of the Slave Craton, excluding data and translation effects of the Lac de Gras field $(\mathrm{n}=64)$. Circles superposed on the data cluster represent distances of 25, 50,100,250, and $500 \mathrm{~km}$ from the origin. Circular histograms display data density within $5^{\circ}$ azimuthal sectors (maximum count values are indicated).

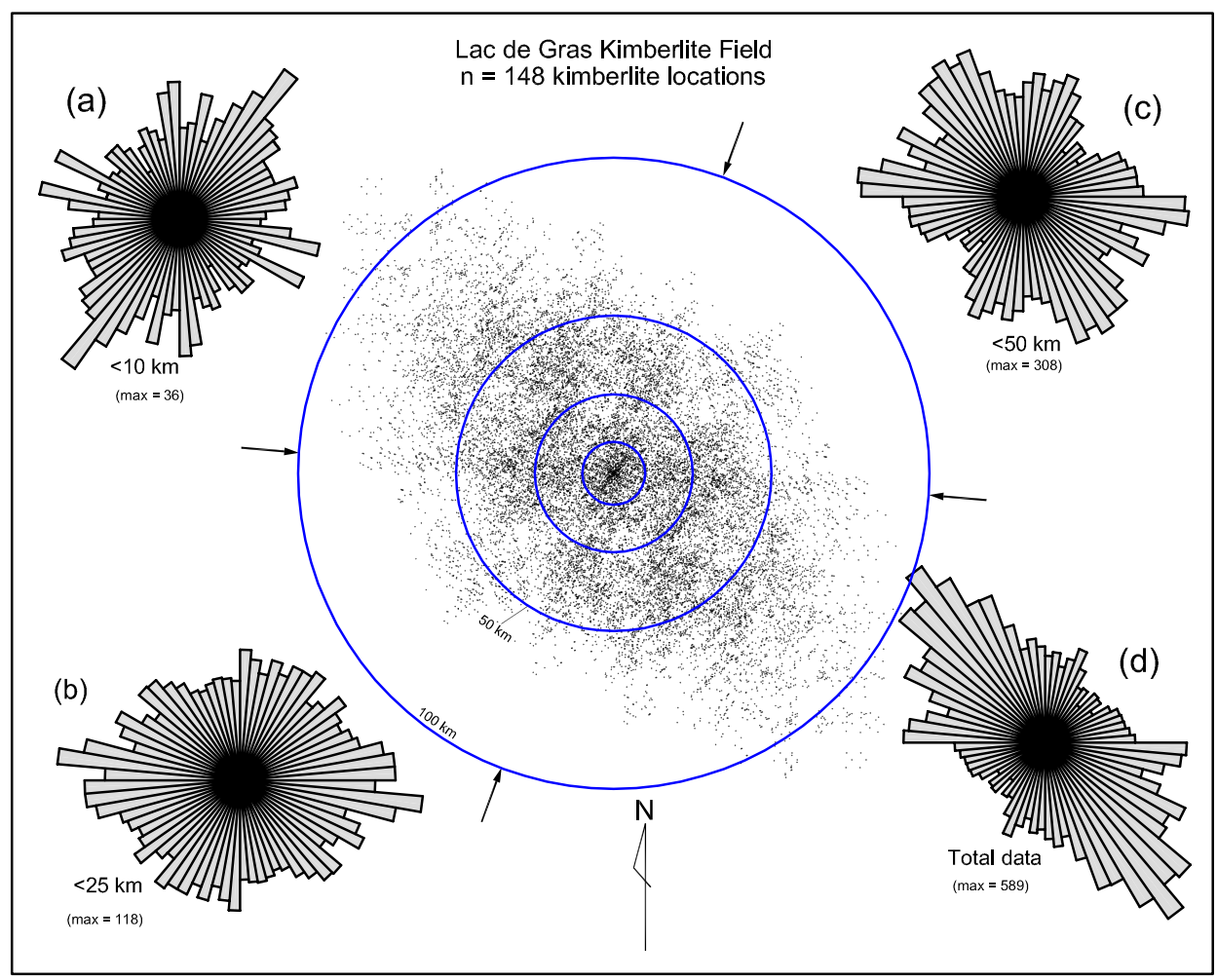

Figure 3: "Fry Plot" for kimberlite of the Lac de Gras field $(n=148)$. Circles superposed on the data cluster represent distances of $10,25,50$, and $100 \mathrm{~km}$ from the origin. Circular histograms display data density within $5^{\circ}$ azimuthal sectors (maximum count values are indicated). 


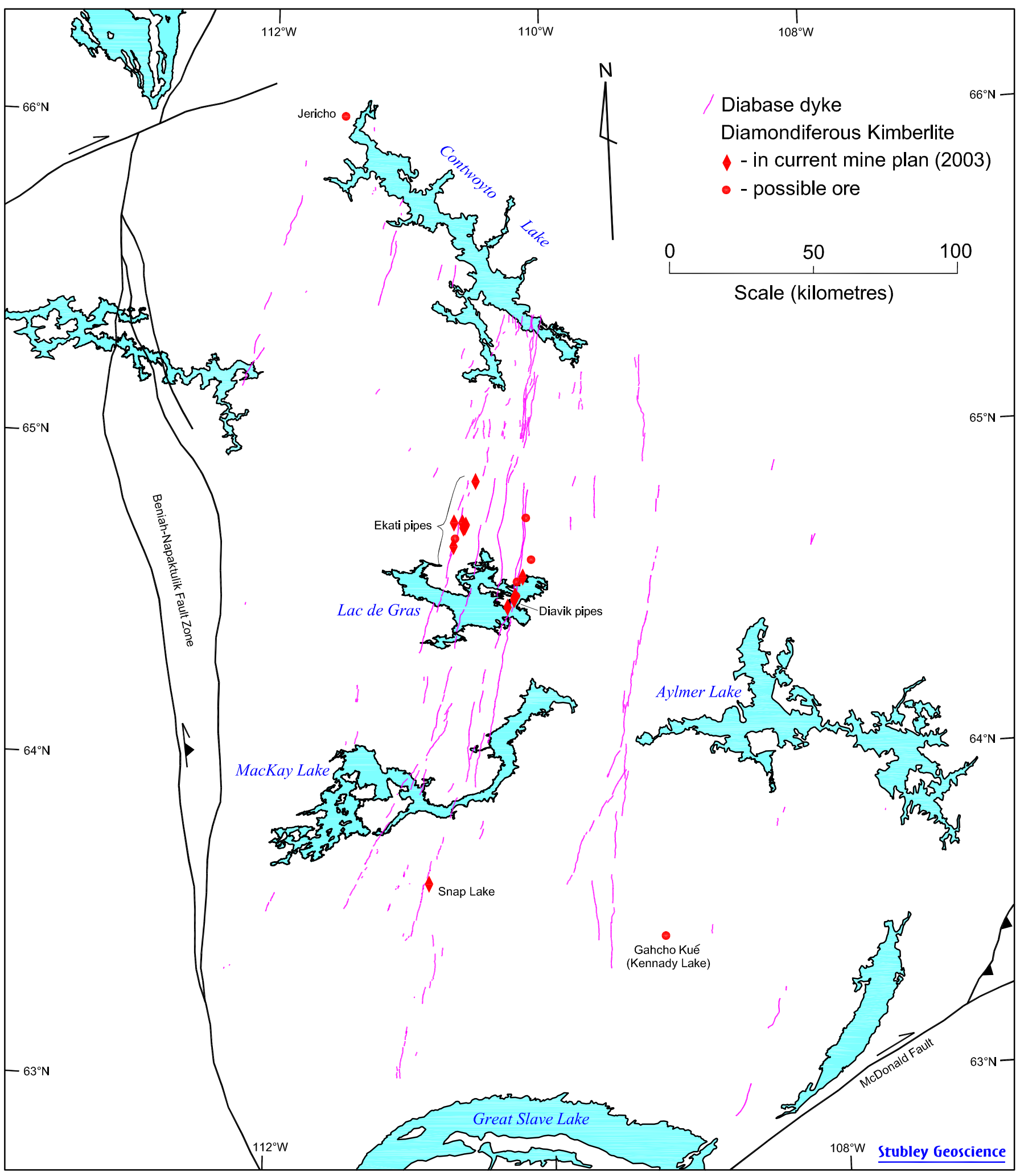

Figure 4: Kimberlite of the Slave craton currently slated for production or subject to advanced feasibility study. North-northeast striking diabase dykes, presumably of the ca. $2.0 \mathrm{Ga}$ "Lac de Gras" swarm, are illustrated for the area south of Contwoyto Lake and east of the Beniah-Napaktulik fault zone. 